UDC 336

\title{
FAIRNESS ASSESSMENT ANALYSIS OF ACQUISITION TRANSACTION
}

\author{
Ciputri Anora Gaus \\ Accounting and Appraisal Service, Faculty of Economics and Business, \\ University of Brawijaya, Indonesia \\ E-mail: anoragaus@gmail.com
}

\begin{abstract}
The purpose of this study is to analyze or test the fairness of acquisition transactions. The object of this research is the transaction conducted by PT Bank Windu Kentjana International Tbk ("Company") to acquire the share of PT. Bank Antar Daerah. The valuation method used is Market Approach and Income Approach. The primary data was collected based on Bank Anda's official website. The results reveal that the use of income approach and market approach will generally produce different value estimation for the same company at the same time. There may even be one approach to yielding results that the stock is undervalued while others conclude that its value is overvalued. This happens because the market value approach issues per cut-off values without considering future prospects, income approach considers future prospects by adjusting according to the circumstances of the assessed company. Therefore, it is necessary to reconcile the value to get the fair market value of shares. The Fairness Test of the acquisition transaction price is done by comparing the transaction price with the Fair Market Value of $100 \%$ of Bank Anda's shares with the provision no more and less than $7.5 \%$ of the Fair Market Value of $100 \%$ of Bank Anda's shares then the data is said to be reasonable.
\end{abstract}

\section{KEY WORDS}

Process, fairness analysis, acquisition, stock valuation, market approach, income approach.

Global economic growth still faces pressure for weakening throughout 2015, it occurs since the weakening in the United States, a developed country playing a role as the world's economic center, caused by the decrease of consumption level and export. While India and several developing countries in ASEAN face an economic slowdown in the third quartal of 2015. Global economic performance grows $3.4 \%$ in 2014 and falls off by $3.1 \%$ in 2015 .

Indonesia's economic growth still faces an increase, although goods and services export falloff caused by the price of the commodity going down too is still in accordance with the decrease of oil price and global economic running into the volume deceleration of world trade. In the other side, the size of the government role in form of buildings and non-buildings infrastructure investment, in form of consumption, the government plays an important role to accelerate economic growth in Indonesia, while the private sector is still limited to the investor waiting for an unpredictable economic condition. The role of the capital market is essential to accelerate national economic growth, one of the determiners of Gross National Product is an investment. Investment is divided into two, i.e. financial sector investment like share investment, bonds, etc., and real investment like an investment in building infrastructure (bridge, roads, etc.) which supports the economy.

Investment analysis has 2 approaches, namely fundamental analysis and technical analysis (Fabozzi, 1999). Fundamental analysis has security assessment basis divided into two models, i.e. asset values and earning multiplier (Pasaribu, 2008). While technical analysis is a technique of market activity statistic analysis in the past used to project price movement in the future (Ong, 2008).

Price of moveable share is based on the internal factor like distribution of dividend, acquisition, and publication of financial statement and external factors like economic growth, inflation rate, and currency growth. In this case, Porman (2008) also states that capital market is not only an investment land anymore but also a business speculation place which can bring profit and loss to the investor. According to Halim (2005:20), this is why company's 
intrinsic value plays an important role to make a decision in purchasing company share so that before making a decision, it is necessary to conduct share valuation to know the risk of that investment.

Share assessment is divided into two, i.e. non-financial corporation assessment by separating operational cash flow and funding as well as financial company assessment with funding cash flow for company operational as raw material, in which there are many regulations that have to be met (mandatory minimum capital requirements).

A study on the determination of company value that then becomes share market value has been done a lot. Several prior studies related to the assessment or company share assessment are as follows: Tauriesanto (2007) conducted share assessment of PT. Bank Negara Indonesia Tbk for share divestment planning of Bank BNI year 2007 conducted by the government to assess whether it is undervalued or overvalued. It was conducted using historical data from 2002 until 2006. The result of this research is the price of BNI share traded on the Indonesia Stock Exchange (Bursa Efek Indonesia or BEI) compared to the estimation of its intrinsic value using Discounted Cash Flow (DCF) method and the relative valuation by Rp3.139,4 (\$0.24) until Rp3.442 (\$0.26) faces an undervalued.

In order to herald Asean Economic Community (AEC), Indonesia has to be ready in every sector of the economy, no exception in financial sector especially the bank. The weak of the competitiveness of Indonesia's banking in international level encourages Bank Indonesia to discourse a consolidation of national banking by conducting merger and acquisition. Merger and Acquisition are expected able to become a solution for national banking to go international. In addition, Bank Indonesia is not the only one party which discourses merger since the government through the Minister of State-Owned Enterprise plans a holding company formation. For instance is what happened to PT Bank Windu Kentjana Internation Tbk to support national banking consolidation, conducting acquisition with PT Bank Antar Daerah.

PT Bank Windu Kentjana International Tbk hereinafter referred to as "company" is a foreign exchange bank which is the merger of PT Bank Multicor Tbk and PT Bank Windu Kentjana conducted on January 8, 2008. Corporation share has been noted on the Indonesia Stock Exchange since 2007. The company has signed notarial sale \& purchase agreement in which Bank Anda as the shareholder with acquisition value reaches up to Rp517,913 trillion. The book value of Bank Anda per June 30, 2016, is Rp232.478 trillion. the company acquires Bank Anda with ratio price to book value by 2.23 times. As a comparison, according to the IDX Statistics per first quartal of 2006, the average of price to book value of banking company listed on the $\mathrm{BEl}$ is 1.35 times.

According to the explanation above, the transaction value of Bank Anda's acquisition share by a higher company if compared to the average of price to book value of banking listed on the Indonesia Stock Exchange. The writer intends to conduct a reappraisal of Bank Anda's share market value using income approach and Discounted Cash Flow method as well as market approach and Guideline Company Method. The reason why the researcher performs this transaction is that corporation is a public company where there is a minority group that has to be protected by Financial Services Authority and Indonesia Stock Exchange. According to that background, the writer needs to study: "Fairness Assessment Analysis for Acquisition Transaction".

\section{LITERATURE REVIEW}

Definition of Acquisition. The acquisition is a strategy that can be used by a company to expand its business without starting from the first. The acquisition is conducted by purchasing the partial or the entire company ownership. Statement of Financial Accounting Standards (Pernyataan Standard Akuntansi Keuangan or PSAK) Number 22 states that acquisition is the form of company ownership acquisition by an acquirer, so that will cause control moving for the acquirer. Intended company control is the power to:

- Set the financial policy and company operational;

- Appoint and reject management; 
- Get majority voting rights on the board of directors meeting.

A company getting involved in the acquisition juridically still stands and operated independently, but having been experienced a transfer of control by an acquirer. Acquirer having majority of the share is eligible to use his/her voting stock that is commonly shown for the ownership of more than 50 percent of that voting stock share. If the amount of the share is less than 50 percent, the acquirer can also be stated as the majority vote owner if the acquisition-company articles of association mention that matter. However, the owner having $51 \%$ of share is possible to not state as the majority voting owner if company's articles of association mention other things. The explanation concludes that acquisition is the form of entire of partial take over of company's share ownership so that causing the movement of company's control.

The Role of Fairness Opinion. Fairness opinion will be very useful if it is a product of a result of research or discourse conducted by independent company's financial expert, it aims to provide an objective standard in which the manager, shareholder and interest group can assess the chance faced by company (Clements et.al, 2005). The following are the fairness opinion:

1. Mitigating fiduciary. Fairness opinion can be evidence that the manager has made a decision carefully and is full of goodwill for interest and in accordance with the view and objective of the company, as required by article 95 paragraph 5 of Law Limited Company. Fairness opinion can be guidance for them from claim possibility of the loss experienced by the corporation because of the decision made. However, Haubert (2005) said in a discussion held by NACD (National Association of Corporate Director) that even tough fairness opinion offers significant legal safeguards for the manager; s/he cannot consider that the safeguards have been completed.

2. Aiding fiduciary in decision making. A document enclosing a letter of fairness opinion conducted by a competent independent business assessor is based on the due diligence towards the business interest being transaction object, industrial course and other information of financial economy getting involved with the transaction will be sufficient information to make a decision of the intended transaction.

3. Material to ease the acquisition of shareholder approval (enhancing communication). Within a company management, there is an asymmetry condition between company and shareholder as the company owner, so that it needs a special effort from the manager to make shareholder agree on the transaction of a corporation that will be conducted. One of the ways can be done is providing transaction fairness opinion from the independent side.

Income Approach in a Business Assessment. Business Assessment uses three assessment approaches, namely:

- The market approach is comparing the assessed company with the same company, company ownership right or the same share sold in public market. Data sources can be obtained from the same share market traded or prior transaction for company ownership;

- The income approach is estimating the current value of the future income, including growth rate and time expected, the risk will happen, and space and time value;

- Asset approach is accommodating the whole asset and liability of market value considered appropriate to the balance sheet. If this approach is applied to going concern, value estimation given should also consider value estimation of other approaches. (SPI 2015, KPUP; 4.8, 14).

\section{METHODS OF RESEARCH}

This was quantitative research, the object of this research was the transaction conducted by PT Bank Windu Kentjana International Tbk ("Company") to acquire the share of PT. Bank Antar Daerah. The data was collected by documenting information published on Company and Bank Anda's official website. Bank Anda's share valuation is based on the internal and external analysis. The internal analysis will be conducted based on the data posted on Bank Anda's official website, historical analysis of Financial Position Report, 
Comprehensive Income Report, and Flow Cash Report. Bank Anda's prospect in the future is evaluated based on the business plan and projection. The external analysis is based on the brief study towards external factors considered as value drivers and brief study on the prospect of the related industry.

In order to apply various assessment methods to decide Market Value of a "business interest", it is necessary to refer to the representative financial report, for that matter it needs a book value adjustment of Financial Position Report and benefit normalization of Comprehensive Income Report that is commonly made by accountant based on the historical value. No matter how much book value of a company reflected in a statement of financial position and Comprehensive Income Report are sales figure and not reflect the economic value that can fully become a reference of company's fair value during that assessment.

In order to decide Bank Anda's Fair Market Value, we apply two types of approach, i.e. income approach (Discounted Cash Flow - DCF) and market approach (Guideline Company Method - GCM). The assessment was conducted using DCF method as the major assessment approach and GCM method as the second assessment approach. Those approach and assessment method above is the matter which the writer considers most relatable to be applied in this research.

Income approach with DCF method is based on the projection of clean cash flow determined based on the projection of company's economic approach after being subtracted by required expenditures to support company operational like working capital additional and cost of capital. The market value of the share was then obtained by discounting cash flow projection for a shareholder with applicable discount rate to obtain Equity Market Value.

Market approach by applying GCM is conducted by estimating company's share value based on the share market price of proportional and matched companies listed as a public company on the regional stock exchange. This method will build on the valuation multiples of other proportional and matched companies estimated having scale and characteristic of business which is almost same as the company which will be assessed. This research result can decide the most reflective value of Bank Anda.

After obtaining Bank Anda's Share Fair Market Value for every method used, the next step was conducting value reconciliation to gain Bank Anda's share market value. Bank Anda is a close corporation whose share is not traded on the stock exchange so that the writer adds Control Premium and cuts Discount Lack of Marketability or DLOM. The following is the process of Bank Anda's share valuation.

\section{RESULTS AND DISCUSSION}

Fairness assessment of acquisition transaction using top-down analysis approach can entirely determine macroeconomic, industry and company's target. Macroeconomic provides a picture which is in accordance with state economic policy including inflation, rate, economic growth, a balance of payment position and other macroeconomic conditions. Industry analysis provides a picture of the competitor condition in the industry, target company position compared to the competitor and policy as well as regulation related to the industry. Target company analysis relates to the historical condition of target company, company management analysis, value chain analysis of the target company.

Transaction fairness is needed to protect the importance of minority shareholder so that the transaction gives added value for not only majority shareholder but also the entire shareholder, which then can enjoy the positive impact of the transaction. Fairness for the transaction will build on the comparison between fair market value compared to transaction value. The fair market value will build on the share assessment result that has been conducted based on the provision and matched assessment approach to be applied to the target company.

Approach and Methodology. Approach selection and assessment method that will be applied will build on the assessment analysis to the relevance between approach and methodology that will be used with object characteristic which will be assessed and data availability that will be used. The researcher chooses income approach (Discounted Cash 
Flow - DCF) since the characteristic of the assessed company is the one resulting in income, and income is a value driver as requirement compliance in income approach, in addition, the availability of external and internal data make the researcher projection assumption. The second approach used is market approach (Guideline Company Method - GCM), because there is a matched and proportional company on the stock exchange with the assessed company (its industry meant is banking, its company assessment is Commercial Bank Business Group (Bank Umum Kelompok Usaha) 1, its industrial position is financial), and its earning and equity is positive as requirement compliance in the market approach method, in this case, the researcher gets information from Bloomberg. While the asses approach is not used since in addition to require property assessment, fixed asset assessed is not a value driver, company's fixed asset has been contributed to result in income, this kind of approach is more matched for a company that is still in the stage of development, not operated commercially yet, a company having no income history with positive prospect, or a company doubted its ability to continue an operation with going concern, or a company under a trouble to get an income, or having big fixed asset, like properti company or mining company that is not operated yet. While Bank Anda has operated commercially today, so the researcher comments on that income approach using DCF method and market approach with GCM approach is the most relevant ones to this research.

Income Approach. Bank Anda's Financial Projection Assumption will build on the internal and external analysis. After deciding projection assumption used, the next step the researcher does is calculating Financial Report Projection based on the projection assumption that has been formed. The next step was estimating beta and cost of equity calculation. Beta estimation is obtained from the average of leverage beta of Competitor Company got from Bloomberg. Leverage Beta also can be calculated manually with Hamada equation.

Table 1 - Beta Estimation and Cost of Equity Calculation

\begin{tabular}{|c|c|c|c|}
\hline \multicolumn{2}{|c|}{ Unlevered Beta of Competitor Company } & \multicolumn{2}{|c|}{ Cost of Equity Calculation } \\
\hline & Levered & Equity Cost & \\
\hline Company & Beta $^{(1)}$ & Free Risk Rate & $6.77 \%$ \\
\hline PT Bank Capital Indonesia Tbk & 0.63 & Market Risk Premi & $7.57 \%$ \\
\hline PT Bank Mestika Dharma Tbk & 0.46 & Levered Beta & 0.58 \\
\hline PT Bank Woori Saudara Indonesia 1906 Tbk & 0.76 & & \\
\hline PT Bank QNB Indonesia Tbk & 0.39 & Equity Cost & $11.19 \%$ \\
\hline PT Bank Mitraniaga Tbk & 0.61 & & \\
\hline PT Bank Rakyat Indonesia Agroniaga Tbk & 0.76 & & \\
\hline PT Bank Dinar Indonesia Tbk & 0.43 & & \\
\hline PT Bank Windu Kentjana International Tbk & 0.64 & & \\
\hline Average & 0.58 & & \\
\hline Mean & 0.62 & & \\
\hline
\end{tabular}

Source: Processed Data.

The reason why the researcher uses Beta leverage is that within banking assessment, it cannot be separated between debt and equity, since the thing sold in banking business is its debt (Deposit Ratio or Dana Pihak Ketiga or DPK), and then channeling it into loan, and that loan results in an income in form of lending rate, the income will results in net revenue and net revenue will increase equity. That is the cycle so that can be concluded that it cannot separate debt and equity, DPK is the main fund source in the banking, so in order to maximize income, banking will increase DPK and funds channeling in form of the loan.

Cost of equity is obtained from Risk-Free added by Beta multiplied by Risk Premium, in which Risk-Free is obtained from Government bond throughout 30 years in online cash subtracted by default from Damodaran and risk premium based on the premium of Indonesia's market risk per December 31, 2015, from Damodaran. Risk-Free is obtained from Government bonds since the only one security that has a chance for free risk is government securities, not because the government is better performed than a company, but because they control bank notes printing. At least, nominally, they have to be able to fulfill 
the promise. Even though this assumption is it's, but it does not always defend, especially when the government reduces the regulation issued by prior regime and when they borrow currency except their own, so it needs to be subtracted by default.

The risk premium is a fundamental and important component of portfolio management, corporate finance, and valuation. A book entitled "Valuation Approached and Matrics: A survey of the Theory and Evidence" written by Aswath Damodaran, in order to find risk premium by considering the conventional approach, it is done using historical return for the equity and government bonds, and evaluate some of the weakness. Damodaran also checks how the way to extend this approach to the developed country's market, in which historical data tends to be limited and is not stable. Alternative towards historical premiums is estimating equity implied from equity price. This approach obligates to start with valuation model for equity and estimates growth and cash flow expected, collectively, on equity investment. This has a benefit since no need historical data and reflects market perception today.

The next step is finding an indication of Bank Anda's Share Value by projecting net income of 2006 until 2020, subtracted by asset decrease and added by liability obtained from balance projection of 2006 until 2020, so it will result in equity Cash Flow. The calculation of Current Value Cumulative of Net Cash Flow is obtained from Equity Cash Flow multiplied by the discount rate. The indication of fair market value using DCF method is obtained from the calculation of Current Value Cumulative of Net Cash Flow added by Terminal Value current Value, while the terminal value is obtained from terminal value multiplied by Discount Factor year 2020. Terminal Value is obtained from perpetual annuity Cash Flow multiplied by perpetual annuity (GDP- Gross Domestic Product) from BPS and IMF.

Table 2 - Share Value Indication

\begin{tabular}{|c|c|c|c|c|c|c|}
\hline \multirow[t]{2}{*}{$\mathrm{n} / \mathrm{n}$} & PROJ & PROJ & PROJ & PROJ & PROJ & \multirow[t]{2}{*}{ Perpetuity } \\
\hline & 2016 & 2017 & 2018 & 2019 & 2020 & \\
\hline Net Income & 17,139 & 29,513 & 40,233 & 50,133 & 58,378 & 61,297 \\
\hline (Increase) Decrease in Asset & $(327,380)$ & $(284,716)$ & $(249,900)$ & $(268,865)$ & $(181,250)$ & \\
\hline (Increase) Decrease in Liability & 322,238 & 275,862 & 237,830 & 253,825 & 163,736 & \\
\hline Net Cash Flow of Equity & 11,997 & 20,659 & 28,163 & 35,093 & 40,865 & 40,865 \\
\hline Discount Period & 1 & 2 & 3 & 4 & 5 & \\
\hline Discount Rate & $11.19 \%$ & $11.19 \%$ & $11.19 \%$ & $11.19 \%$ & $11.19 \%$ & \\
\hline Discount Factor & 0.90 & 0.81 & 0.73 & 0.65 & 0.59 & \\
\hline Present Value of Equity Net Cash Flow & 10,790 & 16,709 & 20,485 & 22,957 & 24,041 & \\
\hline \multicolumn{2}{|l|}{ Indication of Fair Market Value } & & & & & \\
\hline Cummulative of present Value Arus Net Cash & 94.982 & & & & & \\
\hline \multicolumn{2}{|l|}{ Terminal Value } & & & & & \\
\hline Perpetuity Cash Flow & 40.865 & & & & & \\
\hline Perpetuity & $5.00 \%$ & & & & & \\
\hline Terminal Value & 659,831 & & & & & \\
\hline Discount Factor & 0.59 & & & & & \\
\hline Present Value of Terminal Value & 388,187 & & & & & \\
\hline Indication of fair Market Value & 483,169 & & & & & \\
\hline
\end{tabular}

Source: Processed Data.

Market approach. Within a market approach, the first step that has to do is finding a competitor data, the competitor data is obtained from Bloomberg with the same criterion of business type, i.e. banking, the Company size is same, i.e. BUKU I, its industrial position is finance and positive multiple. We can see multiple positive from the result of P/E and P/BV multiple results of each competitor company. The next step was finding the cost of standard deviation using Standard Deviation with the average of multiple $P / E$ and P/BV of the competitor data, if the result is approaching 0 (zero) it will better because it marks that the competitor data more likely to similar to the company we assessed.

The indication of Bank Anda's P/E multiple share value is obtained by multiplying net income of 2005 with the average of multiple P/E. While the indication of Bank Anda's P/BV multiple share indications is obtained from transferring Equity Book Value 2015 with P/BV multiple averages. 
Table 3 - Competitor Company

\begin{tabular}{|c|c|c|c|c|c|c|c|}
\hline Competitor Company & $\begin{array}{c}\text { Competitor } \\
\text { Country }\end{array}$ & Share Code & Currency & Last FS & Adj Beta & $\mathrm{P} / \mathrm{E}$ & $\mathrm{P} / \mathrm{BV}$ \\
\hline PT Bank Capital Indonesia Tbk & Indonesia & BACA IJ Equity & IDR & $31 / 12 / 15$ & 0.625 & 14.46 & 1.25 \\
\hline PT Bank Mestika Dharma Tbk & Indonesia & BBMD IJ Equity & IDR & $31 / 12 / 15$ & 0.455 & 26.50 & 2.82 \\
\hline PT Bank Woori Saudara Indonesia 1906 Tbk & Indonesia & SDRA IJ Equity & IDR & $31 / 12 / 15$ & 0.763 & 21.04 & 1,35 \\
\hline PT Bank QNB Indonesia Tbk & Indonesia & BKSW IJ Equity & IDR & $31 / 12 / 15$ & 0.393 & 16.27 & 1,05 \\
\hline PT Bank Mitraniaga Tbk & Indonesia & NAGA IJ Equity & IDR & $31 / 12 / 15$ & 0,609 & 1.11 & 1,61 \\
\hline PT Bank Rakyat Indonesia Agroniaga Tbk & Indonesia & AGRO IJ Equity & IDR & $31 / 12 / 15$ & 0.763 & 13.83 & 0.82 \\
\hline PT Bank Dinar Indonesia Tbk & Indonesia & DNAR IJ Equity & IDR & $31 / 12 / 15$ & 0.429 & 18.14 & 0.59 \\
\hline PT Bank Windu Kentjana International Tbk & Indonesia & MCOR IJ Equity & IDR & $31 / 12 / 15$ & 0.641 & 29.10 & 1.39 \\
\hline \multicolumn{6}{|c|}{ Average } & 21.31 & 1.36 \\
\hline \multicolumn{6}{|c|}{ Mean } & 19.59 & 1.30 \\
\hline \multicolumn{6}{|c|}{ Deviation Standard } & 6.78 & 0.67 \\
\hline \multicolumn{6}{|c|}{ Coef of Standev } & 0.32 & 0.50 \\
\hline
\end{tabular}

Source: Processed Data

Table 4 - Share Value Indication of P/E Multiple

\begin{tabular}{|c|c|}
\hline \multicolumn{2}{|c|}{ P/E Multiple } \\
\hline Net Income & 7.633 \\
\hline P/E Multiple & 21.31 \\
\hline Market Value Indication & 162,631 \\
\hline
\end{tabular}

Source: Processed Data.

Table 5 - Share Value Indication of P/BV Multiple

\begin{tabular}{|c|c|}
\hline \multicolumn{2}{|c|}{ P/BV Multiple } \\
\hline Equity Book Value & 222,681 \\
\hline P/B Multiple & 1.36 \\
\hline Market Value Indication & 02,635 \\
\hline
\end{tabular}

Source: Processed Data.

Fair market value indication using market approach is the calculation of $\mathrm{P} / \mathrm{E}$ multiple Share value Indication multiplied by the weight of $20 \%$ and P/BV Share Value Indication multiplied by the weight of $80 \%$. The weight of P/E multiple is smaller by $20 \%$ compared to the weight of P/BV multiple since Book Value is a Value Driver from the banking industry, in which when it will grow, banking will be stand to keep the Capital Adequacy Ratio (CAR) and its main component is equity.

Table 6 - Fair Market Value Indication

\begin{tabular}{|c|c|c|c|}
\hline Method & Value Indication & Weight & Weighted Value \\
\hline P/E Multiple & 162.631 & $20 \%$ & 32,526 \\
\hline P/BV Multiple & 302.635 & $80 \%$ & 242,108 \\
\hline \multicolumn{2}{|c|}{ Indication of Fair Market Value } & 274,635 \\
\hline
\end{tabular}

Source: Processed Data.

In this case, the researcher uses P/E multiple since it is a relative value measurement mostly used, mostly known by, and its simple application makes it an interesting choice for the investor. This ratio is important since the previous researcher has been a long way realized that P/E illustrates the level and quality of growth and risk. Beaver and Morse (1978) relate P/E ratio with fundamental valuation, like what Edwards and Bell (1961) did. Peasnell (1982) made an effort that is more explicit to connect market value with accounting number. Zarowin (1990) sees the relationship between P/E ratio and analysis growth estimation concludes that $\mathrm{P} / \mathrm{E}$ ratio is positively related to the expected long-term growth. While $\mathrm{P} / \mathrm{BV}$ Multiple in a company reflects market expectation towards strength and company cash flow. There are several reasons why investor uses useful P/BV ratio for investment analysis. Firstly is the book value gives intuitive value assessment which is relatively stable that can be compared to market value. Secondly, through accounting standards which consistent 
enough in the whole company, $\mathrm{P} / \mathrm{BV}$ ratio can be compared to the same company to get valuation marks of under or overvalued condition.

There is a small research documenting usage statistic of this multiple and then compare it. Damodaran (2002) notes that the use of multiple is various among the sector, with P/E multiple dominates business valuation and price ratio to general ratio in a company assessment of financial service. Fernandez (2001) presents an evidence of relative popularity from different multiple in a research of bank investment - Morgan Stanley Europe notes that P/E ratio is the most often used. Liu et al. (2002) compare how good different multiple is in a price determination of 1987 , in which the observation is conducted during 1982 and 1999 and shows that profit multiple of the loan per share is best projected in explaining price differently and multiple of book value falls in the center. Lie and Lie (2002) study 10 different multiply in 8261 companies between 1998 and 1999 and gets the same conclusion.

Market Share Reconciliation of 100\% Share. Income approach and market approach commonly will result in different value estimation for the same company at the same time. Even maybe there is an approach to get a result that the share is undervalued while the other concludes that its assessment is assessed too high. This happens since, at the market approach, the value allocated is per cut-off values, without considering the future prospect, while income approach considers the future prospect by being adjusted to the assessed company condition.

There is a small research documenting the statistic of income approach and market approach usage, i.e. Kaplan and Ruback's (1995) study examining transaction price paid for 51 companies in a leverage purchase transaction and concludes that the valuation of discounted cash flow results is the most similar value with GCM, at least for a company within their sample. They use compressed APV approach which is explained in the prior part to estimate discounted cash flow value and EBIT and EBITDA multiple to estimate relative value. Berkman et al. (2000) use P/E ratio and assessment model of discounted cash flow to assess 45 companies that are newly listed on the New Zealand Stock Exchange and concludes that those two approaches explain about $70 \%$ from price various and having the same accusation. Kim and Ritter (1999) have different finding, they assess a group of IPO uses P/E and price ratio to book and concludes that multiple only has simple prediction ability. Evidence seems contradiction can be explained by a fact that a study with market approach run well in accordance with a similarity between competitor shares, while a study considering from approach view concludes that intrinsic valuation is more beneficial.

Table 7 - 100\% Share Value Reconciliation

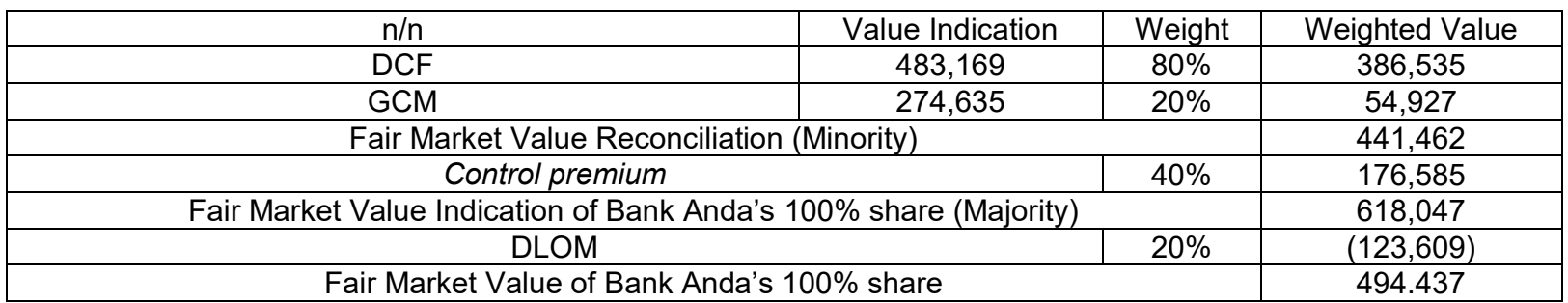

Source: Processed Data.

For that matter, after getting Fair Market Value of Bank Anda's Share for every method used, and then conducting value reconciliation to get a fair market value of Bank Anda's share. Fair market value reconciliation (minority) is obtained from the calculation of DCF method multiplied by the weight of $80 \%$ and GCM method with the weight of $20 \%$. Weight provision will build on the consideration that the value resulted from GCM method is per cutoff values, without considering the future prospect, while the value resulted from DCF method is a value that has considered by adjusting company condition assessed.

Fair Market Value of Bank Anda's 100\% share (majority) is obtained by summing up reconciliation of fair market value (minority) with Control Premium by $40 \%$ of the 
reconciliation of fair market value (minority). Fair market value of Bank Anda's $100 \%$ share is obtained from the calculation of a Fair market value of Bank Anda's $100 \%$ share (majority) subtracted by $20 \%$ of DLOM and multiplied by an indication of the fair market value of Bank Anda's $100 \%$ share (majority). Control premium by $40 \%$ and DLOM by $20 \%$ will build on the regulation of BAPEPAM VIII C 3 concerning assessment guidance and report presentation of business assessment in the capital market.

The reason why the researcher subtracts with DLOM is because the capital price formation of business interest (enclosing in a company) in a market for corporate control commonly indicates that Public Company's (Tbk) share price is higher than close corporations (Ttp), this is caused by public companies share is considered having higher selling power and can be converted into cash quickly, for that matter, in an assessment process of close corporations' share enclosing in a context of market value exploring data from market to the resulted value indication, should be subtracted by discount since unavailability to be marketed quickly (Discount for Lack Of marketability). This discount is a compensation that has to be accepted by an investor for the liquidity (share an inability to be converted into money quickly) from that close corporations. According to the copy of the Decision of Capital Market and Financial Services Supervisory Agency (Bapepam-LK) Head No. KEP-196/BL/2012, Regulation Number VIII C3 concerning Assessment Guidance and Business Assessment Report Presentation in Capital Market, Market Liquidity Discount (Discount for Lack of Marketability) for not a public company of majority shareholder is between $20 \%$ until $40 \%$ from Value Indication.

In order to decide the estimation of the number of DLOM is obligated to consider several factors that influence, among others,

- Size of distribution during holding period is how often, big and sure dividend acceptance is accepted by the shareholder. The more sure, often and big the acceptance, the smaller the discount applied. In this case, according to audit statement, Bank Anda routinely conducts dividend division to the shareholder.

- Prospect for liquidity, share that has a prospect to be disbursed in a particular frame time that can be predicted will affect the amount of DLOM. In this case, Bank Anda as close corporations, its share has fewer prospects to be disbursed in a particular frame time.

- The pool of Potential Buyers, the bigger the number of the potential buyer, the lower the DLOM. In this event, Bank Windu plans to invest in a company engaged in the same field, i.e. banking by conducting acquisition of Bank Anda's 100\% share.

- Risk Factor, the level of business risk which is higher will affect DLOM.

Therefore, in order to consider the condition above, DLOM used is $20 \%$.

In this study, the researcher chooses to add control premium since the reconciliation result of fair price value is minority share while the research object is a majority one, so control premium additional or control premium is a number of particular percentages which is additional of an equity value that results in minority share if the assessed object is majority. According to the copy of the Decision of Capital Market and Financial Services Supervisory Agency (Bapepam-LK) Head No. KEP-196/BL/2012, Regulation Number VIII C3 concerning Assessment Guidance and Report Presentation of Business Assessment in Modal Market, Premium for Control for a closed corporation that can be used in an assessment between $30 \%$ until $70 \%$ of the Value Indication.

In order to decide the amount of the Control Premium that needs to be considered is the higher the ability to control and manage a company or business policy, the higher the control premium given. Therefore, in order to consider the condition above, Control Premium used is $40 \%$.

In this research, the researcher does not use DLOC since DLOC is a discount applied to the indication of equity value obtained from the application of business assessment method that results in majority share value if the equity object assessed is minority, while equity object that the researcher assesses is majority and equity indication obtained from application of business assessor that the researcher produced is minority share value. 
Fairness Test Analysis of Acquisition Transaction Value. Fairness test of acquisition transaction price was conducted by comparing transaction price and Bank Anda's $100 \%$ fair Price Value under the provision of no more or less than $7.5 \%$ of Bank Anda's $100 \%$ share Fair Market Value so that the data is reasonable. The provision of no more or less than $7.5 \%$ is based on the decision copy of Bapepam and LK head No. KEP-196/BL/2012, Regulation Number VIII C3 concerning Assessment Guidance and Business Assessment Report Presentation in Capital Market. The range of $+/-7.5 \%$ is decided to make transaction value approved not undervalued or overvalued and there is no injured party.

Table 8 - Transaction Fairness Analysis

\begin{tabular}{|c|c|c|c|c|}
\hline $\begin{array}{c}\text { Transaction } \\
\text { Object }\end{array}$ & $\begin{array}{c}\text { Fair Market Value of } \\
\text { Bank Anda's Share }\end{array}$ & $\begin{array}{c}\text { Transaction } \\
\text { Value }\end{array}$ & $\begin{array}{c}\text { \% Transaction Value } \\
\text { towards Fair market Value } \\
\text { of Bank Anda's Share }\end{array}$ & $\begin{array}{c}\text { Transaction } \\
\text { Price Fairness }\end{array}$ \\
\hline $\begin{array}{c}1,603,308 \text { of } \\
\text { Bank Anda's } \\
\text { Share }\end{array}$ & $494,437,000,000$ & $517,913,000,000$ & $4.75 \%$ & Fair \\
\hline
\end{tabular}

Source: Processed Data.

Approach selection and assessment method that will be applied will build on the assessment analysis to the relevance between approach and methodology that will be used with object characteristic which will be assessed and data availability that will be used. The researcher chooses to use income approach (Discounted Cash Flow - DCF) and market approach (Guideline Company Method - GCM).

In an Income Approach, projection assumption will build on the internal analysis (Audit Financial Statement of the latest five years) and external analysis (LDR, CAR, and BOPO based on the BUKU, and competence as well as Market Share). For equity cost, the beta used is leverage beta, Risk-Free are obtained from the government bonds, and Risk Premium is from Damodaran.

In a market approach, the most important thing is finding common and rate able competitor data, as well as deciding multiple that will be used. A multiple used in this research is $P / E$ since it is a relative value measurement that is mostly used, mostly known, its application is simple, and illustrating growth equality and risk, while P/BV is used since the book value that can be compared with market value can be compared in the same company to get valuation signs in under or overvalued level.

Income approach and market approach generally will result in different value estimation for the same company at the same time. This happens since the value of market approach issued is per cut-off values without considering the future prospect. While income approach considers future prospect balanced with assessed company condition. For that matter, after getting Share Fair Market Value for every method used, the next step was conducted value reconciliation to obtain its Market Value, with giving weight on each method, the amount of weight given in accordance with assessor's truth supported with proper assumption.

In order to make resulted value is in accordance with the condition of assessed value so that if the indication of equity value obtained is minority share value, it is necessary to add Control Premium if the assessed one is majority share if minority share does not need to be added by control premium. If the indication of equity value obtained is majority share value, it is necessary to be subtracted by DLOC if the one assessed is a minority, if it is majority it does not need to be added by DLOC. If the company assessed is closed corporation, so it needs to be subtracted by DLOM, and if the assessed one is a public company, so it is divided into two, i.e. liquid will be not subtracted by DLOM, if not liquid will be subtracted by DLOM.

In case to assess Price Fairness of Acquisition Transaction by comparing transaction value with share fair market value under the provision of no more or less than $7.5 \%$ of its fair market value, so it can be said fair. The range of more or less than $7.5 \%$ is a range where the transaction is appropriate for all parties to bear the same risk and return. 


\section{CONCLUSION}

This research analyses fairness assessment of the acquisition transaction. The first stage conducted by the researcher is deciding matches type of approach to use by considering object characteristic that will be assessed and relevant data availability with assessment method which will be used. In this research, the researcher uses two approaches, i.e. income approach (Discounted Cash Flow - DCF) since the assessed company characteristic is a company resulting in income and income is a value drive as requirement compliance in an income approach, and external and internal data availability that the researcher can use to decide projection assumption. The second approach used is market approach (Guideline Company Method - GCM) since there are a match and proportional company on the stock exchange with assessed company (its industry is banking, the company's size is BUKU 1, its industry position is finance) and its positive earning and equity as requirement compliance in market approach method.

The income approach is assessment approach by converting economic or income benefit estimated will be resulted by assessment object with particular discount level. Income estimation results from the assumption of finance projection based on the internal and external analysis. While the discount level of this research is Cost of Equity. Cost of Equity is obtained from Risk Free added by Beta multiplied by Risk Premium, in which Risk Free is obtained from government bonds since it is the only one security having a chance to be free risk, since the government who controls money printing, but needs to be subtracted by default since every country has possibility occurred default. Beta is obtained from the average of beta leverage of competitor data since cannot be separated from debt and equity. While Risk Premium is obtained from historical return on the equity and government bonds, and evaluate its weakness.

The market approach is assessment approach by comparing assessment object with other reliably and common object and having selling price. Assessment objects obtained are those listed on the Stock Exchange, those which are common to the type and size business, its industry position, as well as having positive multiple.

Assessment result using income approach and market approach commonly will result in different value estimation for the same company at the same time. Even maybe there is an approach to get a result that the share is undervalued while other concludes that its assessment is assessed too high. This occurs since the value issued for the market approach is per cut-off values, without considering the future prospect, while income approach considers future prospect matched with assessed company condition. For that matter, it needs to conduct reconciliation to get share fair market value. Fairness test of acquisition transaction price is conducted by comparing transaction price with $100 \%$ share Fair market Value of assessed object under the provision of no more or less than $7.5 \%$ of $100 \%$ share fair Market Value of assessed Object share so that data is said valid. The range of more or less than $7.5 \%$ is a range where the transaction is appropriate for all parties to bear the same risk and return.

This research has several limitations, among others, are the data presented by BAPEPAM VIII.C.3 concerning DLOM, Control Premium, and DLOC have not exact provision on how much or should use in this research, the data presented by Aswath Damodaran on Beta Leverage, Control Premium, and Default does not show its calculation process, and the data of Finance projection of self-assumption without doing verification with Bank Anda's management. However, it has been conducted a comparison of the assumption used based on the historical condition, macroeconomic and banking industry.

The researcher suggests in order to invest, especially acquisition, it is better for the investor to keep considering company's share market value acquired by conducting an assessment to the acquired company through independent assessment before conducting acquisition transaction, in accordance with the decision of Bapepam and LK head No. KEP196/BL/2012, Regulation Number IX E 2. In addition, the researcher suggests investor conduct fairness test of the acquisition transaction, since not all acquisition transaction can be profitable for the investor. 


\section{REFERENCES}

1. Beaver, W., \& Morse, D. (1978). What do P/E ration mean?. Journal of Financial Analysts, 34(4), 65-76.

2. Berkman, H., Bradbury, M. E., \& Ferguson, J. (2000). The accuracy of price - earnings and discounted cash flow methods of IPO equity valuation. Journal of International Financial Management and Accounting, 11(2), 71-83.

3. Clements, P.J., \& Philip, W. (2005). The Standar and Poor;s Guide to Fairness Opinions. New York: The Macc Graw Hill Copanies, Inc.

4. Damodaran, A. (2002). Investment Valuation (2nd edition). New York: John Wiley and Sons.

5. Edwards, E., \& Bell, P. (1961). The Theory and Measurement of Business Income. Berkeley: University of California Press.

6. Fabozzi, F. J. (1999). Manajemen Keuangan Teori dan Aplikasi, Manajemen Investasi. Edisi Indonesia. Jakarta: Salemba Empat.

7. Fernandez, P. (2001). Valuation using multiples. How do analysts reach their conclusions?. Working Paper. IESE Business School.

8. Kaplan, S. N., \& Ruback, R. S. (1995). The valuation of cash flow forecasts. Journal of Finance, 50(4), 1059-1093

9. Kim, M., \& Ritter, J. R. (1999). Valuing IPOs. Journal of Financial Economics, 53(3), 409437.

10. Lie, E., \& Lie, H. J. (2002). Multiples used to estimate corporate value. Financial Analysts Journal, 58(2), 44-54.

11. Liu, J., Nissim, D., \& Thomas, J. (2002). Equity valuation using multiples. Journal of Accounting Research, 40(1), 135-172.

12. Ong, E. (2008). Technical Analysis for Mega Profit. Jakarta: Mega Offset.

13. Peasnell, K (1982). Some financial connections between economic values and accounting numbers. Journal of Business Finance and Accounting, 9(3), 361-381.

14. Pasaribu, R. B. F. (2008). Pengaruh Variabel Fundamental Terhadap Harga Saham Perusahaan Go Public di BEI 2003-2006. Jurnal Ekonomi dan Bisnis, 2(2), 101-113.

15. Tambunan, A. P. (2008). Menilai Harga Wajar Saham. Jakarta: Gramedia.

16. Tauriesanto, I. (2007). Penilaian Saham PT. BNI Tbk Dalam Rangka Privatisasi tahun 2007. Yogyakarta: Universitas Gajah Mada.

17. Zarowin, P. (1990). What determines earnings-price ratios: Revisited. Journal of Accounting, Auditing, and Finance, 5(3), 439-457. 